\title{
Desain Modul Model Problem Based Learning (PBL) Berbasis Mind Mapping
}

\author{
Arif Hidayad ${ }^{1, *}$, Andy Eddy ${ }^{2}$ \\ 1,2STKIP Taman Siswa Bima \\ 1'arif.hidayad88@gmail.com, ${ }^{2}$ andyeddy2012@gmail.com \\ ${ }^{*}$ Coresponding Author
}

Artikel Info

Tanggal Publikasi

2019-06-30

Kata Kunci

Desain Modul PBL

Mind Mapping

ADDIE

Validasi

\section{Abstrak}

Penelitian ini bertujuan untuk mengembangkan bahan ajar berupa Desain Modul pada matakuliah Metodologi Penelitian. Materi Desain Modul yang dikembangkan selalu dikaitkan dengan fakta dan masalah di sekitar yang akan dijadikan sebagai dasar bagi mahasiswa dalam mengangkat tema penelitian. Agar terarah dan jelas, materi Desain Modul dikembangkan berbasis "mind mapping" yaitu penjelasan yang saling terkait antara setiap kata, definisi, bagian-bagian, fungsi dan manfaat. Metode penelitian menggunakan model ADDIE yaitu dengan mengambil 3 langkah awal yaitu Analisis, Design dan Development. Penelitian dilaksanakan di STKIP Taman Siswa Bima dengan responden Kaprodi Pendidikan Matematika dan 3 orang ahli sebagai validator yaitu ahli materi, ahli bahasa dan ahli desain. Hasil penelitian didasarkan pada 3 hal yaitu analisis kebutuhan, perancangan blue print dan validasi ahli. Hasil analisa kebutuhan menunjukkan bahwa sangat penting dikembangkan Desain Modul untuk setiap matakuliah khususnya metodologi penelitian sebagai salah satu sumber belajar bagi mahasiswa. Materi yang dikembangkan terdiri dari 6 sub Modul yang disertakan tugas bagi mahasiswa di setiap sub modulnya. Dari penilaian 3 ahli, Desain Modul yang dikembangkan memenuhi kriteria valid dan sesuai dengan kebutuhan matakuliah.

\section{PENDAHULUAN}

Ciri pembelajaran yang baik dan efektif adalah diantaranya pembelajaran yang melibatkan peserta didik secara aktif, menarik minat dan perhatian, membangkitkan motivasi belajar dan melakukan peragaan di dalam kelas saat proses pembelajaran. Agar tercapai ciri tersebut, maka pembelajaran harus didukung oleh tenaga pendidik, perangkat dan bahan ajar dan fasilitas penunjang. Salah satu unsur terpenting adalah tersedianya perangkat dan bahan ajar sesuai materi yang disampaikan. Adanya bahan ajar sekiranya dapat membuat peserta didik terlibat secara langsung berdasarkan materi dan perintah yang ada di dalamnya. Agar dapat terlibat langsung, peserta didik hendaknya mendapatkan masing-masing bahan ajar yang diberikan oleh pendidik agar proses dan target pembelajaran dapat tercapai sesuai harapan. Dalam buku Pedoman Penulisan Buku Pelajaran (Depdiknas, 2005) disebutkan bahwa yang termasuk isi pendidikan adalah segala sesuatu yang oleh pendidik langsung diberikan kepada peserta didik dan diharapkan untuk dikuasai peserta didik dalam rangka mencapai suatu kompetensi tertentu dalam pendidikan.

Dalam konteks perguruan tinggi, khususnya pada matakuliah metodelogi penelitian, mahasiswa wajib dibekali dengan kemampuan berpikir logis. Salah satu cara untuk mencapai kemampuan tersebut adalah melaksanakan praktik pembelajaran yang selalu dikaitkan dengan fakta dan masalah yang terjadi di sekitar. Model pembelajaran tersebut biasa disebut dengan Model Problem Based Learning yaitu pembelajaran berbasis masalah di sekitar. Dengan demikian, mahasiswa diajak untuk memetakan pikirannya terkait masalah yang ditemukan dan bagaimana menganalisanya secara ilmiah agar menjadi sebuah informasi yang bermanfaat bagi pihak terkait. 
Fakta menunjukkan bahwa masih banyak dosen-dosen yang belum memiliki perangkat pembelajaran yang lengkap. Perangkat pembelajaran masih terbatas pada Rencana Pembelajaran Semester (RPS) dan Rancangan Tugas Mahasiswa (RTM). Hal ini tentunya cukup mempengaruhi keefektifan pembelajaran di dalam kelas. Misalnya pada prodi pendidikan matematika, belum tersedianya Desain Modul pembelajaran khususnya pada matakuliah metodelogi penelitian. Dosendosen pengampu matakuliah tersebut belum merancang bahan ajar yang baik dan valid serta sesuai dengan kebutuhan dan keadaan mahasiswa. Akibatnya, banyak mahasiswa yang belum mampu mengemukakan masalah penelitian yang diangkat menjadi judul penelitian.

Bahan ajar merupakan seperangkat sarana atau alat pembelajaran yang berisikan materi pembelajaran, metode, batasan-batasan dan cara mengevaluasi yang didesain secara sistematis dan menarik dalam rangka mencapai tujuan yang diharapkan, yaitu mencapai kompetensi atau subkompetensi dengan segala kompleksitasnya (Chomsin, 2008). Selain itu, bahan ajar pada dasarnya merupakan segala bahan (baik informasi, alat, maupun teks) yang disusun secara sistematis, yang menampilkan sosok utuh dari kompetensi yang akan dikuasai siswa dan digunakan dalam proses pembelajaran dengan tujuan perencanaan dan penelaahan implementasi pembelajaran (Prastowo, 2012).

Oleh karena itu, dosen hendaknya menyiapkan bahan ajar misalnya Desain Modul secara mandiri yang sesuai dengan matakuliah dan dikaitkan dengan permasalahan di sekitar, khususnya dosen pengampu matakuliah metodelogi penelitian. Setidaknya ada empat syarat terpenuhi bila bahan ajar dikatakan baik, yaitu 1) cakupan materi atau isi sesuai dengan kurikulum, 2) penyajian materi memenuhi prinsip belajar, 3) bahasa dan keterbacan baik, dan 4) format buku atau grafika menarik (Puskubruk, 2012).

Matakuliah metodelogi penelitian diberikan kepada mahasiswa dengan tujuan agar mahasiswa mampu menyusun proposal penelitian secara mandiri dengan baik dan benar. Melalui matakuliah tersebut, mahasiswa juga diajak untuk berpikir ilmiah dan logis dalam memahami fakta dan permasalahan yang ditemukan disekitar mereka. Selain itu, capaian lulusan yang diharapkan adalah mahasiswa memiliki kecakapan dalam menulis berbagai karya ilmiah ketika sudah lulus. Sebagai penunjang, bahan ajar yang melatih mahasiswa untuk menulis fakta yang ditemukan harus disediakan. Dalam hal ini, Desain Modul model Problem Based Learning (PBL) Berbasis Mind Mapping dianggap cocok dan sesuai dengan kebutuhan perkuliahan. Model pembelajaran berdasarkan masalah (PBL) merupakan suatu model pembelajaran yang didasarkan pada banyaknya permasalahan yang membutuhkan penyelidikan autentik yaitu penyelesaian nyata dari permasalahan yang nyata (Trianto, 2010). Selain itu bahwa model PBL merupakan model pembelajaran yang dapat membantu peserta didik untuk aktif dan mandiri dalam mengembangkan kemampuan berpikir dalam memecahkan masalah melalui pencarian data sehingga diperoleh solusi yang rasional dan autentik (Riyanto, 2009).

Dari pendapat para ahli tersebut, maka dapat didefinisikan bahwa PBL merupakan model pembelajaran yang mengajak peserta didik untuk belajar secara mandiri tentang bagaimana memahami permasalahan dan situasi nyata di sekitarnya dan berpikir untuk menemukan solusinya secara autentik berdasarkan analisis data riil di lapangan.

Desain Modul model PBL berbasis Mind Mapping berisikan beberapa subDesain Modul yang disertakan dengan lembaran tugas mahasiswa. Materi Desain Modul disesuaikan dengan model pembelajaran PBL yakni pembelajaran yang dapat membantu peserta didik untuk aktif dan mandiri dalam mengembangkan kemampuan berpikir dalam memecahkan masalah melalui pencarian data sehingga diperoleh solusi yang rasional dan autentik (Riyanto, 2009). Selain model PBL, Desain Modul juga di kemas dalam tampilan yang menarik dengan tujuan mengajak mahasiswa untuk 
memaksimalkan kerja otak dalam mengaitkan sesuatu hal yang satu dengan yang lain atau biasa disebut Mind Map. Dengan merancang mind map kita telah memanfaatkan dua belahan otak yaitu otak kanan dan otak kiri. Otak kiri terampil untuk memikirkan logika, angka, analisis, dan urutan. sedangkan otak kanan terampil dalam hal irama, keadaran ruang, imajinasi, warna dan dimensi (Buzan, 2005). Selain itu, Mind mapping (peta pikiran) merupakan teknik pemanfaatan keseluruhan otak dengan menggunakan citra visual dan prasarana grafis lainnya untuk membentuk suatu kesan yang lebih dalam (Femi, 2010).

Agar Desain Modul ini tepat sesuai kebutuhan, sesuai tujuan perkuliahan dan layak untuk digunakan, maka pengembangannya berdasarkan keadaan awal yang ada di prodi seperti kurikulum, ketersediaan bahan ajar dan karakteristik mahasiswa. Selanjutnya, blue print yang dirancang dikonsultasikan dengan para ahli agar memperoleh rekomendasi valid. Jika telah valid, maka Desain Modul dapat diujicobakan ke peserta didik dengan harapan mampu mengefektifkan pembelajaran.

Dengan adanya Desain Modul ini, diharapkan mahasiswa yang mengikuti matakuliah metodologi penelitian memiliki kemampuan berpikir logis dan memanfaatkan kerja otak kanan dan kiri dalam memahami masalah dan fakta serta mampu memikirkan langkah analisis ilmiah apa yang harus dilakukan sebelum membuat kesimpulan terhadap permasalahan tersebut.

\section{METODE PENELITIAN}

Penelitian ini merupakan penelitian pengembangan yang menggunakan metode ADDIE (Analysis, Design, Development, Implementation, Evaluation). Dalam penelitian ini, langkah yang digunakan meliputi 3 langkah yaitu Analysis, Desaign dan Development. Anaysis bertujuan untuk mengumpulkan informasi mengenai kebutuhan pengembangan Desain Modul. Desaign yaitu penulisan blue print materi dan kesluruhan isi Desain Modul. Development yaitu melakukan validasi Desain Modul oleh para ahli tentang isi dan tampilan Desain Modul yang dikembangkan.

Penelitian ini dilakukan selama 4 bulan yaitu mulai Januari sampai dengan April 2019 yang bertempat di STKIP Taman Siswa Bima. Penelitian difokuskan pada prodi pendidikan matematika untuk matakuliah metodologi penelitian yang berada pada semester VI (genap) tahun akademik 2018/2019.

Data penelitian diperoleh dari berbagai responden yaitu Kaprodi Pendidikan Matematika, dosen serumpun, ahli materi, ahli desain dan ahli bahasa. Teknik pengumpulan data menggunakan teknik wawancara, FGD (forum group discussion) dengan para dosen, pembagian angket validasi kepada para ahli dan dokumentasi. Instrumen yang digunakan adalah lembar wawancara, angket validasi dan alat dokumentasi. Skor validasi ahli diberikan dalam skala $1-5$ dimana $1=$ tidak relevan/tidak baik, 2=kurang relevan/kurang baik, 3=cukup relevan/cukup baik, $4=$ relevan/baik dan $5=$ sangat relevan/sangat baik. Selanjutnya, skor validiasi ahli dianalisis dengan rumus:

$$
P=\frac{f}{N} x 100
$$

Keterangan:

$$
\begin{array}{ll}
\mathrm{P} & =\text { Nilai Validitas } \\
\mathrm{F} & =\text { Skor perolehan } \\
\mathrm{N} & =\text { Skor maksimum }
\end{array}
$$

(Daryanto, 2014)

Selanjutnya nilai validitas yang diperoleh akan dikonsultasikan dengan tabel kriteria kevalidan agar diketahui kriteria validitas Desain Modul yang dikembangkan. Berikut tabel kriteria kevalidan yang digunakan: 
Tabel 1. Kriteria Kevalidan Bahan Ajar

\begin{tabular}{ccc}
\hline No & Nilai (P) Kevalidan & Kriteria \\
\hline $\mathbf{1}$ & $81-100$ & Sangat Tinggi \\
$\mathbf{2}$ & $61-80$ & Tinggi \\
3 & $41-60$ & Cukup Tinggi \\
4 & $21-40$ & Rendah \\
$\mathbf{5}$ & $0-20$ & Rendah Sekali \\
\hline
\end{tabular}

Jika hasil validasi oleh ketiga ahli berada pada kategori minimal "tinggi”, maka Desain Modul yang dikembangkan dapat digunakan dan valid baik secara materi, desain maupun bahasa.

\section{HASIL DAN PEMBAHASAN}

Secara umum, hasil penelitian ini mencakup 3 hal yaitu hasil Analisis Kebutuhan, Desain Blue Print Desain Modul dan Validasi Para Ahli.

Anaysis (Analisis Kebutuhan)

Data analisis kebutuhan diperoleh melalui kegiatan wawancara tidak terstruktur dengan kaprodi pendidikan matematika tentang input, proses dan output pelaksanaan pembelajaran pada matakuliah metodologi penelitian selama dua tahun terakhir.

Dari segi input, dosen-dosen yang pernah mengampu matakuliah metodelogi penelitian belum pernah mengajar dengan menggunakan Desain Modul. Mereka hanya sebatas menggunakan Rancangan Pembelajaran Semester (RPS) dan Rancangan Tugas Mahasiswa (RTM) sebagai perangkat perkuliahan. Selain itu, dosen-dosen juga menggunakan buku paket dalam mengajar. Hal itu disebabkan oleh belum adanya bahan ajar berupa Desain Modul yang dibuat oleh dosen. Pada prosesnya, praktik perkuliahan matakuliah metodelogi penelitian masih berlangsung secara konvensional dan biasa-biasa saja. Dosen masih mengikuti pola-pola mengajar yang mengikuti perintah dalam buku paket tanpa memperhatikan kebutuhan dan karakter belajar mahasiswa. Mahasiswa sebatas diberikan tugas secara teoritis tentang materi, dan sangat kurang diberikan tugas secara praktis berupa survey lapangan, atau pengambilan data atau masalah nyata yang ada di sekitar. Mahasiswa tidak pernah dibiasakan untuk terjun langsung ke lapangan dalam mengamati hal-hal yang sekiranya bisa diangkat menjadi bahan penelitian mereka dalam rangka penyelesaian tugas akhir (skripsi). Akibatnya, output mahasiswa setelah mengikuti matakuliah metodelogi penelitian tidak memberikan hasil yang sebanding dengan nilai akhir yang diberikan. Hal tersebut terlihat dari ketidakmampuan beberapa mahasiswa dalam merancang judul penelitian, mengungkapkan masalah penelitian, mengungkapkan tujuan penelitian serta hal-hal lain yang berkaitan dengan kegiatan penelitian. Imbas akhirnya adalah mahasiswa mengalami keterlambatan dalam penyelesaian tugas akhir serta sulit "move on" sehingga rasa percaya diri untuk menyusun tugas akhir secara mandiri terkikis secara perlahan dan mahasiswa terpaksa meminta bantuan kepada orang lain.

Desaign (Blue Print Desain Modul)

Berangkat dari hasil analisis kebutuhan yang dilakukan, maka peneliti mencatat poin-poin penting sebagai dasar dalam mendesain blue print Desain Modul. Sebelum penulisan blue print, peneliti melakukan Forum Grup Discussion (FGD) dengan kaprodi pendidikan matematika dan dosendosen yang mengajar matakuliah metodologi penelitian. Hasilnya adalah beberapa dosen menganjurkan pemilihan materi harus disesuaikan dengan tujuan perkuliahan dan misi prodi. Dan setiap tugas yang diberikan harus dikaitkan dengan permasalahan yang ada di sekitar kehidupan sehari-hari agar mahasiswa mampu belajar secara langsung dalam memahami masalah atau memaknai fakta yang terjadi. Selain itu, dalam kegiatan FGD tersebut, para dosen sangat mengapresiasi 
pengembangan Desain Modul ini agar suatu saat dapat digunakan juga oleh mereka dalam mengajar matakuliah yang sama.

Hasil FGD tersebut, dijadikan tambahan referensi oleh peneliti dalam mendesain blue print Desain Modul. Agar Desain Modul dapat disesuaikan dengan kebutuhan dan keadaan mahasiswa, maka Desain Modul didesain oleh peneliti dalam bentuk mind mapping yaitu menjelaskan materi berbentuk peta dan menghubungkannya dengan berbagai hal terkait. Selain itu, agar pembelajaran lebih hidup Desain Modul didesain dengan model pembelajaran PBL berdasarkan keadaan di sekitar. Adapun contoh blue print Desain Modul yang di desain oleh peneliti dapat dilihat pada gambar 1 dan gambar 2 berikut ini:

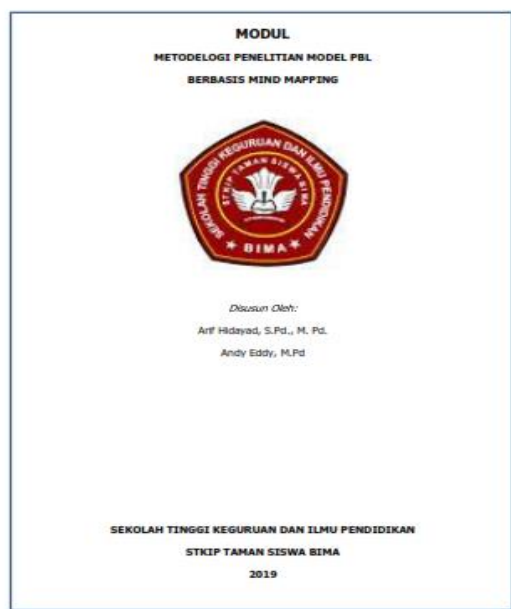

Gambar 1. Sampul Desain Modul PBL berbasis Mind Mapping

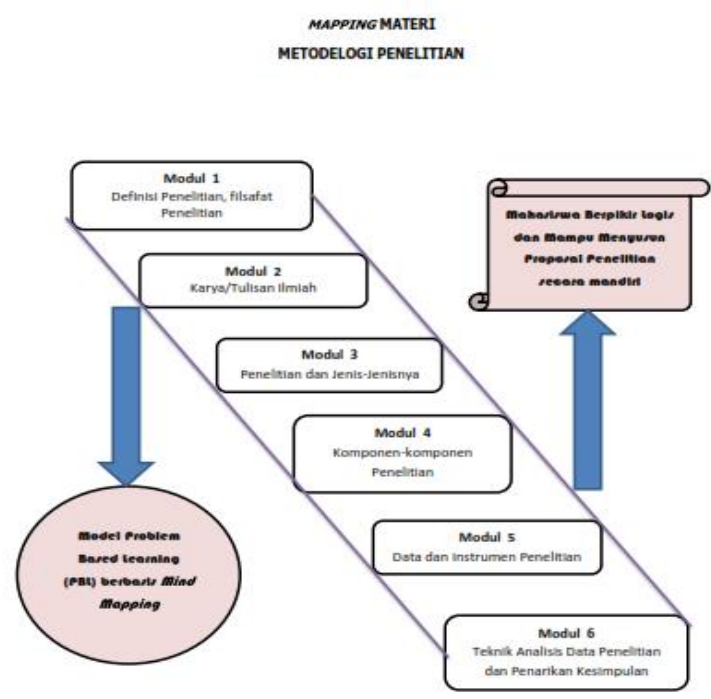

Gambar 2. Mapping Materi Desain Modul

Desain Modul yang didesain berisikan 6 subDesain Modul yaitu Desain Modul 1 sampai Desain Modul 6. Setiap subDesain Modul selalu disertai dengan tugas mahasiswa. Tugas diberikan secara individu maupun kelompok. Tugas dikaitkan dengan kehidupan sehari-hari dan mahasiswa 
dibiasakan untuk terlibat secara langsung dan turun ke lapangan untuk mengambil data dan informasi yang akan dianalisis dan di tarik kesimpulannya. Penentuan materi tersebut didasarkan pada capaian pembelajaran dan capaian lulusan yang diharapkan setelah menempuh matakuliah metodologi penelitian. Dibagian akhir Desain Modul, peneliti melampirkan panduan penulisan skripsi jenis kualitatif, kuantitatif dan penelitian pengembangan.

\section{Development (Validasi Ahli)}

Pada tahap development, peneliti mengajukan desain Desain Modul kepada para ahli untuk meminta pendapat dan pertimbangan tentang kevalidan Desain Modul. Jumlah ahli sebanyak 3 orang yaitu ahli materi, ahli desain dan ahli bahasa. Para ahli diberikan lembar validasi yang akan diisi. Lembar validasi ahli materi mencakup: relevansi (M1), keakuratan (M2), kelangkapan sajian (M3), konsep dasar materi (M4), dan sajian materi yang berpusat pada siswa/mahasiswa (M5). Selanjutnya, lembar validasi ahli desain mencakup: tampilan umum (D1), tampilan khusus (D2) dan penyajian Desain Modul (D3). Sedangkan lembar validasi ahli bahasa mencakup: penggunaan bahasa (B1), ketepatan bahasa (B2) dan konsistensi (B3).

Tahap validasi ini dilakukan sebanyak 2 tahap. Hal tersebut dikarenakan pada tahap I, masih belum mencapai skor yang diharapkan atau berkategori "tinggi" pada semua ahli sehingga perlu dilakukan revisi sesuai dengan arahan para ahli. Secara rinci, skor validasi yang diperoleh dapat dilihat pada tabel 2 berikut ini:

Tabel 2. Hasil Validasi Ahli terhadap Desain Modul

\begin{tabular}{cccccccc}
\hline Ahli & Indikator & \multicolumn{2}{c}{ Skor P Validasi } & \multicolumn{2}{c}{ P rata-rata } & \multicolumn{2}{c}{ Kriteria } \\
\cline { 2 - 7 } Materi & Tahap I & Tahap II & Tahap I & Tahap II & Tahap I & Tahap II \\
& M1 & 60 & 64 & & & & \\
& M2 & 50 & 75 & & & & \\
& M3 & 60 & 80 & 54 & 79,8 & cukup tinggi & Tinggi \\
& M4 & 60 & 100 & & & & \\
& M5 & 40 & 80 & & & & \\
Besain & D1 & 50 & 60 & & & & \\
& D2 & 60 & 106,6667 & 55 & 82,222 & cukup tinggi & Sangat Tinggi \\
& D3 & 55 & 80 & & & & Sangat Tinggi \\
& B1 & 80 & 90 & & & & \\
& B2 & 80 & 100 & 73,333 & 90 & & \\
\hline
\end{tabular}

Terjadinya peningkatan skor validasi dari berbagai ahli dikarenakan sebelum melaksanakan validasi tahap II, peneliti merevisi Desain Modul sesuai dengan arahan dan catatan yang diberikan oleh para ahli. Catatan tersebut diantaranya tentang perluasan materi yang ditampilkan, penambahan tugas-tugas mahasiswa, penjelasan garis, panah dan warna pada berbagai gambar dan diupayakan di setiap sub Modul disediakan contoh riil sesuai dengan judul subDesain Modul.

Pada ahli materi, peningkatan skor validasi dari tahap I ke tahap II sebesar 47,7\% dan terjadi perubahan ke kriteria tinggi. Selanjutnya, pada ahli desain peningkatan cukup signifikan dari validasi tahap I ke tahap II yakni sebesar 49,4\% dan terjadi perubahan kriteria ke "Sangat Tinggi". Terakhir, pada ahli bahasa juga terjadi peningkatan skor validasi dari tahap I ke tahap II yakni sebesar 22,7\% serta terjadi perubahan kriteria ke "Sangat Tinggi". Artinya, perubahan skor dan kriteria validasi yang signifikan terjadi pada ahli desain. Hal itu dapat digambarkan pada gambar 3 berikut: 


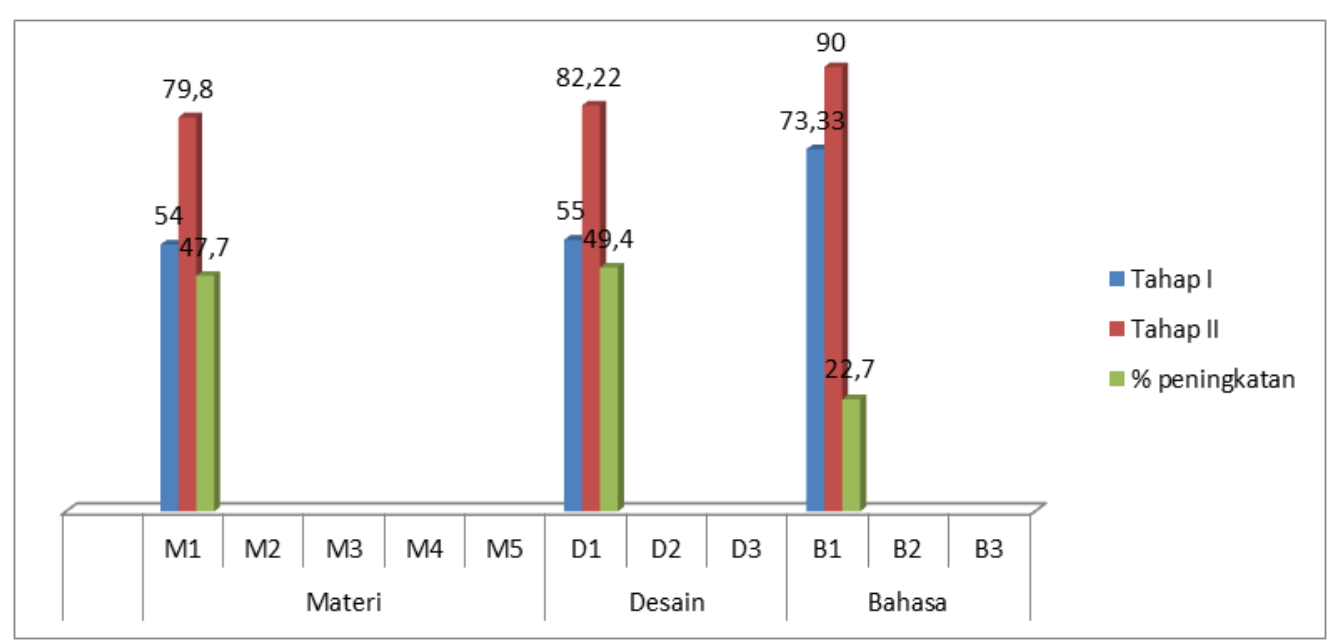

Gambar 3. Grafik Peningkatan Nilai Validasi

Meskipun berbeda dari segi skor peningkatan pada ketiga ahli, kevalidan bahan ajar/Desain Modul yang dikembangkan terletak pada kenaikan skor pada validasi tahap II. Artinya, revisi yang dilakukan pada hasil tahap I cukup maksimal. Dari ketiganya, semua menyatakan bahwa desain modul yang dikembangkan telah memenuhi syarat minimal dan valid secara kuantitatif serta dapat digunakan sebagai bahan ajar matakuliah metodelogi penelitian.

\section{SIMPULAN}

Sesuai dengan tujuan penelitian yaitu mengembangkan desain modul model PBL berbasis mind mapping dan temuan data serta pembahasan yang telah dilakukan, maka dapat disimpulkan bahwa desain modul Model Problem Based Learning (PBL) berbasis Mind Mapping ini telah memenuhi kategori valid oleh ketiga ahli yaitu ahli materi, ahli desain dan ahli bahasa. Ketiga ahli menyatakan bahwa kevalidan desain modul yang dikembangkan berada pada kategori tinggi dan sangat tinggi.

\section{Daftar Pustaka}

Buzan, Tony. 2012. Buku Pintar Mind Map. Jakarta: PT.Gramedia Pustaka Utama.

Chomsin S. Widodo, Jasmadi. 2008. Panduan Menyusun Bahan Ajar Berbasis Kompetensi. Jakarta: Gramedia.

Daryanto. (2014). Pengembangan Perangkat Pembelajaran (Silabus, RPP, PHB, Bahan Ajar) Yogyakarta: Gava Media.

Depdiknas.2005. Panduan Pengembangan Model Pembelajaran Berbasis Kompetensi. Jakarta: Direktorat PPTK dan KPT Dirjen Dikti

Femi Olivia. 2010. Visual Mapping. Jakarta: PT. Elex Media Komputendo.

Pollit, David. 2003. Mind Mapping your way to a better career. Journal of Career Development International, Vol.8 Iss 5 pp.253-256.

Prastowo, Andi. 2012. Panduan Kreatif Membuat Bahan Ajar Inovatif. Yogyakarta: Diva Press.

Puskurbuk. (2012). Pergeseran paradigma belajar abad 21. Retrieved August 1, 2015, from http://www.puskurbuk.org

Trianto. 2010. Model Pembelajaran Terpadu. Jakarta: Bumi Aksara

Yatim Riyanto. 2009. Paradigma Baru Pembelajaran. Jakarta: Kencana Prenada 